\title{
Lukács e a problemática cultural da era stalinista ${ }^{1}$
}

José Paulo Netto ${ }^{2}$

\section{Apresentação}

Ronaldo Vielmi Fortes 3

Há exatos 40 anos, a revista Temas de ciências humanas, publicava o texto de um já proeminente intelectual brasileiro, que versava sobre o pensador marxista húngaro György Lukács, havia algum tempo presente nos debates da esquerda brasileira. O texto cumpria o papel de defender e explicitar a posição de Lukács frente à vaga stalinista que avassalou grande parte do projeto socialista no período em que vigorou, no assim chamado Leste europeu, a república dos sovietes.

Bastante questionado desde a realização do XX Congresso do Partido Comunista, ocorrido após a morte de Stálin, o socialismo real transfigurava as marcas indeléveis de ampla série de atrocidades e descaminhos que deixavam claro seu distanciamento das linhas traçadas pelos clássicos do marxismo na efetivação do projeto de uma sociedade comunista. No interior dos debates sobre tais desvirtuamentos abriram-se as portas para a crítica contumaz da posição de diversos intelectuais comunistas frente ao fenômeno do agora questionável stalinismo. Seus apoiadores e opositores figuravam no cenário internacional como algozes ou mártires do regime opressor de Stálin. Estranhamente, Lukács, a despeito de significativa quantidade de artigos e depoimentos críticos por ele escritos ao longo de anos, passou nesse contexto a ser tachado como

1. Este ensaio não se pretende à clarificação do complexo de relações entre Lukács e aquilo a que, à falta de melhor e mais precisa nomenclatura, denomino "era stalinista"; o seu objetivo é contribuir para esse esclarecimento, focando apenas o que me parece pertinente para compreender o posicionamento de Lukács em face de proposições filosóficas e estéticas próprias daquela era. Apesar da intencionalidade explicitamente didática deste texto, esforcei-me por não fazer concessões à maior parte da bibliografia referente ao tema (e que o leitor pode rastrear principalmente em MÉSZÁROS, 1972): recuso-me quer a considerar Lukács um sequaz da dogmática, quer a idealizá-lo acima dela - penso que as conexões entre Lukács e as consequências do modelo de socialismo que derivou do fracasso da revolução concebida "classicamente" (isto é: no Ocidente industrializado e burguês) são multívocas e particularmente complexas. Devo observar, ainda, que a concepção da obra lukacsiana que subjaz a este escrito difere substancialmente daquela que enformou outras intervenções minhas; gostaria que a posição evidenciada agora (dezembro de 1978) fosse tomada como o meu trânsito de uma "lukacsofilia" sincera para uma apreciação crítica do extraordinário pensador. [Publicado originalmente na revista Temas de Ciências Humanas, São Paulo, Ciências Humanas, n. 6, 1979. Republicado em: COTRIM, Ana; COTRIM, Vera (Orgs.). Todo poder aos sovietes! A Revolução Russa 100 anos depois. Porto Alegre: Zouk, 2018. Agradecemos às organizadoras e à editora pela autorização para publicação na Verinotio. Revisado por Vânia Noeli Ferreira de Assunção. Nota dos Editores - NE]

2 Professor Titular da Universidade Federal do Rio de Janeiro (UFRJ).

3 Professor da Universidade Federal de Juiz de Fora (UFJF). E-mail: rvielmi@hotmail.com. 
stalinista. Foi visto e denunciado aos "quatro cantos" por muitos como um defensor acrítico do sistema.

O artigo de José Paulo Netto, na ocasião de sua publicação, tinha por objetivo principal resgatar a verdade sobre as relações de Lukács com o regime ditatorial de Stálin. A partir dos escritos do pensador húngaro, da investigação criteriosa da participação política de Lukács nos tempos em questão, assim como por meio do resgate de sua relação conturbada com o Partido Comunista, Netto traz à tona o lado desconhecido de nosso pensador - para não dizer propositadamente descurado por seus detratores -, no qual transparece de maneira clara a crítica áspera e ao mesmo tempo responsável de Lukács em relação às diretrizes assumidas pela direção do partido soviético. São lembrados seus posicionamentos no evento de 1956, quando do acontecimento da revolução húngara, trazidos à memória também vários artigos e livros da época, nos quais aparece de modo evidente o rechaço efetivo das vias assumidas pelo socialismo real na era stalinista.

Contra aqueles que sugeriam ser esta uma postura assumida apenas após o XX Congresso, no entanto, Netto, de maneira bem rigorosa, traz à baila a variedade de artigos escritos por Lukács entre os anos de 1930 a 1945, período em que o pensador húngaro residia na então URSS, em que fica patente sua oposição às diretrizes do $\mathrm{PC}$, em particular, seus escritos profundamente críticos à política cultural dogmática impetrada pelo stalinismo. Se o confronto não pôde se dar diretamente sob a forma de um debate aberto sobre as fundamentações assumidas pelo regime, dada a forte repressão da polícia política de Stálin, fica patente em seus escritos da época que as afirmações de Lukács são “o oposto das formulações dogmáticas". Todo o conjunto de debates em torno das questões literárias e estéticas mostram com clareza, como observa Netto, o rechaço contundente da "concepção stalinista-zdhanovista do marxismo".

O trágico é perceber a atualidade do texto que ora se republica. Se outrora a investigação séria da biografia e da bibliografia do autor empreendida por Netto fazia emergir o intelectual crítico dos descaminhos do processo concreto do socialismo soviético, servindo de combate direto à má compreensão das posturas políticas e filosóficas de Lukács - seja por desconhecimento, por má vontade ou má intenção -, sintomaticamente, em nossos dias, o texto de Netto mostra-se atualíssimo na medida em que a figura distorcida de um Lukács stalinista ainda contamina o cenário de certos redutos acadêmicos e intelectuais brasileiros e mesmo internacionais.

Não importa sua motivação - desconhecimento, má vontade ou má intenção -: a persistência de tal incorreção tende a obscurecer e por vezes "lançar entulho" sobre o vigor do pensamento lukacsiano, bloqueando o 
entendimento da herança filosófica deixada por suas reflexões, importantíssimas nos dias atuais tanto para a autocrítica das diretrizes históricas assumidas pelo socialismo real como para a retomada do projeto revolucionário.

O que foi arma eficaz contra a má compreensão da figura política e filosófica de Lukács, hoje, por motivos talvez outros, ainda se mostra capaz de desempenhar o mesmo papel de eficácia ao se colocar novamente como arma crítica, cuja função precípua é trazer de volta à discussão a força de um pensamento autenticamente revolucionário.

Não é a primeira vez e provavelmente não será a última que a Revista Verinotio volta a este tema. Antes, o artigo de Nicolas Tertulian4, de título Lukács e o stalinismo, escrito em 2002, contribuiu para desfazer a mesma imagem de um intelectual vinculado ao stalinismo, ao combater uma série de críticos contemporâneos difusores de tal acusação. O resgate destes textos, ambos sérios e rigorosos em seus argumentos, põe-se como tarefa necessária. Se o que foi escrito foi muito bem demonstrado e argumentado, é desnecessário escrever com outras palavras o que está estabelecido com precisão e rigor. Aspecto que justifica a republicação do artigo de Netto, não por mero resgate da memória dos debates teóricos - e, por que não dizer, políticos - de uma época em particular, mas como a arma crítica contra os descaminhos do presente.

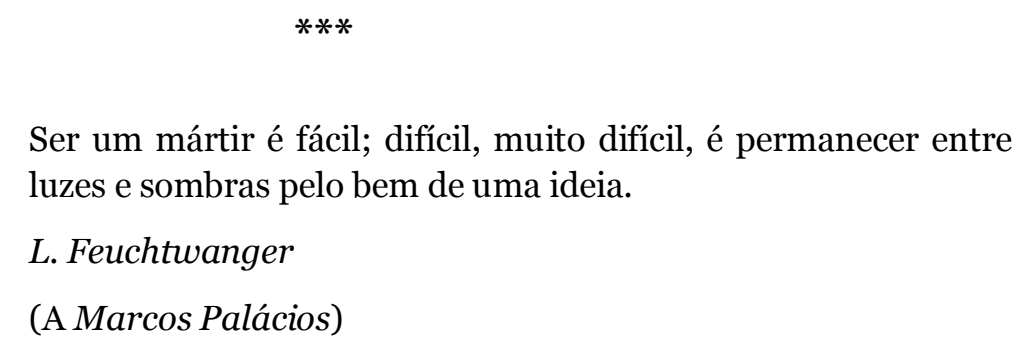

Assim como nenhum pensador responsável do século $X X$ pode eximir-se de um confronto com o marxismo, nenhum pensador marxista pode elidir-se de um exame do stalinismo, um dos resultados do fracasso da Revolução no Ocidente.

O stalinismo - núcleo nevrálgico do mais dramático traumatismo sofrido pelo movimento operário revolucionário contemporâneo - não afetou apenas, ainda que em todos os níveis, a nova sociedade construída pelo povo russo (e, mesmo que assim fosse, revestir-se-ia de crucial significação). Muito mais: o que constitui a problemática da era stalinista comprometeu o socialismo como novo padrão societário. De fato, somente a íntima compreensão daquela problemática pode evidenciar que não se trata de uma necessária decorrência da passagem

4 Publicado no n. 7 desta revista, de novembro de 2007. Disponível em: <http://www.verinotio.org/conteudo/o.65943372031621.pdf>, acesso em 31 mar. 2019. 
do capitalismo ao comunismo, mas sim de uma contrafação muito específica da transição socialista que se opera sem o respaldo de um processo revolucionário mundial e num contexto de capitalismo subdesenvolvido.

É óbvio que um comprometimento deste gênero atingiu profundamente o marxismo - a pesada herança da problemática da era stalinista configura, objetivamente, um elemento de ponderável peso na história (incluída a que se desenrola atualmente) do marxismo. Eis por que, neste contexto, o posicionamento de um filósofo como Lukács é de essencial importância quer para a inteligência do seu próprio pensamento, quer para o esclarecimento das reais dimensões da problemática mesma do stalinismo.

Esse posicionamento, no correr dos últimos 30 anos, tem suscitado as mais contraditórias polêmicas. De um lado, há os que se alinham com Leo Kofler, para quem "Lukács e o stalinismo distinguem-se entre si como o socialismo liberal distingue-se do socialismo burocrático. Entre eles não há nenhuma ponte”. De outro, há os que supõem, como Youssef Ishaghpour, da parte de Lukács, uma "adesão mais ou menos tácita ao stalinismo".

Quer-me parecer, todavia, que o objetivo e isento estudo das relações entre a obra (e mesmo a biografia) de Lukács e a sistemática stalinista patenteia entre ambos uma complexa rede de conexões, evidenciando, ao mesmo tempo, um denodado esforço do filósofo no sentido de demarcar-se daquela terrível deformação e daquele brutal desvio do marxismo, no quadro histórico posto pelo confinamento da Revolução na Europa de Leste.

Escapa inteiramente aos objetivos deste breve ensaio a análise da era stalinista5: o foco do interesse deve recair sobre a problemática cultural a ela pertinente. De qualquer forma, um sumário excurso histórico-crítico será útil para situar a questão.

Stálin (Joseph Vissarionovich Djugashivili, nascido em 1897), precoce militante dos movimentos socialistas russos, participou ativamente da Revolução de 1917 e atuou com destaque no período da Guerra Civil. Vagarosa, mas seguramente, galgou a hierarquia do Partido Comunista e, em 3 de abril de 1922, era nomeado secretário-geral do Comitê Central da organização. Após a morte de Lênin, em 21 de janeiro de

5. Da vastíssima bibliografia sobre o tema, ver especialmente a obra antiga, mas indispensável, de I. Deutscher (1970). Para um tratamento mais recente, ver J. Ellenstein (1975) e ainda os volumes III e IV da sua História da URSS (1976), assim como as anotações críticas dessa argumentação em E. Mandel, Crítica do eurocomunismo (1978). 
1924, abre-se uma etapa de lutas intrapartidárias que só culminará em 1929, quando Stálin impõe a seus pares a expulsão, da Rússia, do seu grande rival, Trotsky ${ }^{6}$. A vitória de Stálin não significou apenas a liquidação política do defensor da teoria da "revolução permanente", com a consequente hegemonia da concepção do "socialismo num só país"7: significou, sobretudo, a gradativa implantação de uma sistemática política que abolia a discussão democrática das alternativas do socialismo estimulada por Lênin -, substituindo-a por uma centralização burocrática do processo de decisões, levadas a cabo por um pequeno círculo funcional aglutinado em torno do secretário-geral.

A instauração de um sistema político autocrático foi concomitante à emergência do que Deutscher chamou de "a grande mudança": a partir de 1929, fundamentais modificações são introduzidas na vida econômica da Rússia - inicia-se a coletivização da agricultura e articula-se o projeto de industrialização acelerada do país, com a elaboração do primeiro plano quinquenal. A significação destas modificações é aferível na apreciação do grande historiador:

Em 1929, cinco anos depois da morte de Lênin, a Rússia soviética aventurou-se à sua segunda revolução, dirigida única e exclusivamente por Stálin. Quanto ao alcance e impacto imediatos sobre a vida de cerca de 160 milhões de pessoas, a segunda revolução foi ainda mais ampla e radical que a primeira. Redundou na rápida industrialização da Rússia; forçou mais de cem milhões de camponeses a abandonarem suas pequenas e primitivas propriedades e fundarem fazendas coletivas; arrancou implacavelmente das mãos do mujique o secular arado de madeira e obrigou-o a segurar a roda de um trator moderno; levou dezenas de milhões de analfabetos para a escola e fez com que aprendessem a ler e escrever; e espiritualmente desligou a Rússia europeia da Europa e colocou a Rússia asiática mais perto da Europa. Os prêmios desta revolução foram espantosos; mas também o foi o seu custo: a perda total, por parte de uma geração inteira, de liberdade espiritual e política. É necessário um grande esforço de imaginação para avaliar a magnitude e a complexidade dessa

6. No seu famoso testamento, redigido quando já enfermo e nunca publicado integralmente na URSS, Lênin advertiu: "Tendo-se tornado secretário-geral, o camarada Stálin concentrou imenso poder em suas mãos; e não estou certo de que ele saberá sempre usar esse poder com bastante cautela" (apud DEUTSCHER, 1970, v. I, p. 222). Quanto a Trotsky, que considerava "pessoalmente (...) o homem mais capaz do atual Comitê Central”, Lênin também teceu reservas.

7. A teoria da "revolução permanente", Trotsky formulou-a ainda em 1906, mas apresentou-a conclusa no livro A revolução permanente (1978), escrito em 1928 e só publicado em 1930. O núcleo do pensamento trotskista era a noção - inspirada nos "clássicos" - segundo a qual a construção do socialismo era variável dependente da revolução mundial. Somente depois de 1924, diante do refluxo do movimento operário europeu, é que Stálin passou a sustentar a possibilidade da edificação do socialismo em um só país. 
transformação social que não tem nenhum precedente histórico. Mesmo levando-se em conta as diferentes proporções dos problemas humanos em outras épocas, os maiores reformadores da história russa, Ivan, o Terrível, e Pedro, o Grande, e também os grandes reformadores de outras nações, parecem anões ao lado do vulto gigantesco do secretário-geral. (DEUTSCHER, 1970, v. I, p. 266)

É no justo processo desta "grande mudança" que o secretário-geral aciona os mecanismos que constituirão a era que leva seu nome - é com ela que o stalinismo passa a inscrever-se como página heroica e sangrenta da história do socialismo. O episódio de excepcionalidade política que acompanhou o período 1929-32, tempo da "grande mudança", foi transformado por Stálin e seu aparelho partidário em norma de conduta política. A compreensível suspensão da democracia socialista num quatriênio de rapidíssimas mutações socioeconômicas foi manipulada pelo aparato partidário num injustificável regime autocrático - a sociedade russa foi envolvida na camisa de força de um abrangente terrorismo psicossocial. É evidente, ademais, que esta excepcionalidade política só pôde erguer-se e manter-se, como fenômeno "superestrutural", expressando determinadas características na organização da economia; ou, na corretíssima síntese de Mandel:

Quanto aos fatos, ensinam que de maneira nenhuma se pode reduzir o "fenômeno stalinista" a fenômenos de superestrutura: terror estatal, ditadura dum homem, polícia todo-poderosa, dogmatismo ideológico etc. Estes fenômenos imbricam-se manifestamente num conjunto de relações sociais e de relações de produção características: ausência de autogestão dos produtores, ausência de autoadministração dos cidadãos e de controle destes sobre a administração política e econômica, planificação burocraticamente centralizada, apropriação e distribuição do sobreproduto social pelo estado, fora de todo o controle dos produtores, regime do diretor único e todopoderoso no seio da empresa, manutenção da estrutura hierárquica desta, sistema de remuneração assegurador de chorudos privilégios para os altos funcionários, submetendo boa parte do proletariado aos horrores do trabalho à peça etc. (MANDEL, 1978, pp. 78-9).

A partir do fracasso da revolução mundial, com o isolamento da Rússia soviética, a ascensão do nazi-fascismo forneceu o pano de fundo para a constituição e o desenvolvimento político da era stalinista. Esta garantiu-se mediante a onipresença do medo, o grande acólito dos períodos de obscurantismo - medo produzido e organizado pelas agências do poder, que, por seu turno, o segregavam intestinamente: à mordaça de todo um conjunto multinacional correspondia a liquidação de segmentos do próprio poder. A sistemática destas liquidações (os famosos "expurgos") assinala, no seu auge, o movimento mesmo de uma estrutura 
política que se afirma na autofagia. Ela atinge seu clímax nos instantes em que a vida social alcança um patamar no qual a sua degenerescência começa a saltar à vista. É assim que, na hora da colheita inicial da semeadura de 1929-32 (em 1936-9), o aparelho stalinista massacra, nos Processos de Moscou, a velha guarda bolchevique; é assim que, após a extraordinária vitória sobre o Eixo, em 1946-9, as "depurações” atingem os melhores quadros militares e guerrilheiros; é ainda assim que, em 1951-3, os sobreviventes veem-se às voltas com a polícia política.

A natureza autofágica do stalinismo estendeu-se para além da morte do secretário-geral (março de 1953): ela somou-se à fragilidade de toda autocracia - a áspera luta pela sucessão -, que culminou, por volta de 1955, na supremacia do grupo de Kruschev. No ano seguinte, no XX Congresso do Partido Comunista da União Soviética (PCUS), Stálin tem despido o seu manto sagrado: abre-se o "degelo", a crítica ao stalinismo.

Esta crítica, contudo, realiza-se por meio (e no meio) daquele mesmo aparelho político-partidário que Stálin pôde construir à sua imagem e semelhança. Não desce ela, compreensivelmente, às raízes efetivas, histórico-sociais, do stalinismo: o aparelho prefere, ao contrário, o cômodo método de atribuir as deformações impostas ao socialismo ao chamado "culto da personalidade". Não se atentou para a indicação de Baran, enunciada logo em seguida à "desestalinização":

Atribuir todos os crimes e erros, cometidos na URSS antes da II Guerra Mundial e, após ela, em todos os países da Europa Oriental e Sul-oriental, às pessoas de Stálin, Béria e colaboradores é praticar o "culto da personalidade" ao contrário. As coisas não são tão simples assim. O sentimento geral (...) é que "todo o sistema", na verdade, deve ser responsabilizado pelo que fez a liderança. (BARAN, 1960, p. 8)

No entanto, quer no XX, quer no XXII Congresso do PCUS, continuou-se a praticar esse "culto da personalidade" às avessas - ou, nas palavras contundentes de Lukács: "O que houve até agora foi o início do processo (...) de desaparecimento do stalinismo na forma de stalinismo” (in: HOLZ; KOFLER; ABENDROTH, 1969, p. 102).

É evidente que tal crítica não supera essencialmente as características da era stalinista: antes prolonga-se, na rota de um verdadeiro neosstalinismo. Procura-se justificar estas limitações básicas na medida em que, desnudando por detrás da legenda de um Stálin "guia genial dos povos" traços de uma personalidade em que se mesclavam, paradoxalmente, a pertinácia com a incultura, a vocação política com a volúpia do poder, a fidelidade à causa revolucionária com o mais feroz sectarismo, a dedicação ao Partido com a idolatria burocrática - procurase justificá-las na medida em que a crítica radical pode conduzir a uma generalizada decepção revolucionária. 
Esta reserva, todavia, não é cabível no interior de um movimento revolucionário que se pretende orientado pelo marxismo. Ela é própria daqueles que, no Partido russo e nos outros Partidos Comunistas também eles, ao longo dos anos entre 1930 e 1956, forjados naquele "aço stalinista" que fazia do reboquismo às soluções russas a pedra de toque da sua existência ${ }^{8}$-, buscam a simples preservação de posições de poder. Por outro lado, essa meia-crítica tende a fortalecer a sua contrapartida burguesa: a pura identificação do stalinismo com o socialismo. O caráter primário de um engodo como este não lhe retira, é claro, a eficácia ideológica: se stalinismo é sinônimo de socialismo, obviamente este se torna medularmente problemático.

De 1956 até hoje, a herança stalinista parece refratária à autêntica análise marxista. Entre o "degelo" manipulado da maioria esmagadora dos Partidos Comunistas (capitaneados pelo russo) e a reação ideológica burguesa, não penetrou ainda, de modo efetivo, a análise orientada pela metodologia marxista - a não ser que se considere legitimamente marxista o folclórico grupo de pretensos heterodoxos, baluartes de uma abstrata independência intelectual, que justifica a sua má consciência ideológica com a fácil recusa do stalinismo na crista de um indisfarçado projeto liberal para o marxismo.

A ausência desta crítica marxista responde precisamente por aquele estado de espírito de que o arguto Ehrenburg se fez porta-voz: "Quanto mais penso em Stálin, mais claramente vejo que não entendo nada." (EHRENBURG, 1970, v. VI, p. 45)

\section{2}

Após 1956, Lukács foi um dos poucos pensadores marxistas que se recusou às facilidades ideológicas do momento - não partilhou do rápido enterro do stalinismo pelos neosstalinistas e não aceitou o liberalismo dos pretensos heterodoxos (aliás, a sua participação os eventos húngaros de 1956 tipifica sua atitude: entre os adeptos de uma "reforma" rakosiana e os defensores de uma "abertura" para o Ocidente, ele preferiu o exílio e a solidão).

Com efeito, Lukács, fiel à sua ortodoxia marxista9, adotou uma postura de dúplice crítica: contra o dogmatismo da era stalinista e contra o liberalismo emergente com a sua denúncia.

Já em 1957, ele assinalava que,

8. Stálin definia como comunista "aquele que, sem evasivas, incondicionalmente, aberta e honestamente, considera a causa da Revolução mundial como sinônimo dos interesses e da defesa da URSS" (apud MANDEL, 1978, p. 43).

9. Para o conceito de ortodoxia marxista de Lukács, cfr. o primeiro ensaio de Histoire et conscience de classe (1965a). 
em matéria literária, nos debates provocados pelo $\mathrm{XX}$ Congresso, verificamos, por um lado, o nascimento de um revisionismo que rejeita toda a crítica marxista da decadência e recusa o próprio princípio do realismo socialista (...). De outro lado, no campo dogmático, esforçam-se por defender em bloco - com reservas para erros "isolados" - toda a doutrina e toda prática dos últimos decênios. Nenhuma dessas atitudes poderia ser a nossa. Também sob este aspecto, o revisionismo (...) só pode ser combatido eficazmente se submetermos o dogmatismo, em primeiro lugar, a uma rigorosa crítica, ao mesmo tempo teórica e prática (LUKÁCS, 1969, pp. 24-5, grifos meus).

Nesta formulação estão contidos os elementos fundamentais do combate travado por Lukács a partir da denúncia da era stalinista: de uma parte, a crítica concreta ao stalinismo e ao neosstalinismo; doutra, a luta contra as tendências liberais. No mesmo texto, ele indicava que a reação ocasionada pela denúncia do stalinismo

toma a forma de revisão da doutrina professada por Marx e Lênin. Hoje é este, sem dúvida, o perigo capital que ameaça o marxismo-leninismo. Mas não é menos evidente que, se queremos fazer face a esta ameaça, precisamos, em primeiro lugar, de romper decisivamente com o dogmatismo de Stálin e do período stalinista: é necessário descobrir lhe a coerência sistemática, os fundamentos metodológicos, as consequências práticas e denunciar dessa maneira tudo o que se opõe ao marxismo-leninismo (LUKÁCS, 1969, p. 24, grifo meu).

A correta estratégia do pensamento marxista posterior ao $\mathrm{XX}$ Congresso do PCUS aparece, pois, segundo Lukács, como devendo estar estreitamente ligada a esta crítica em duas frentes. Da superação da herança da era stalinista não resulta apenas a restauração da essência do marxismo: resultam as condições para derrocar as posições liberais. Mais ainda: as últimas objetivações do pensamento burguês, como o neopositivismo, exigem, para um confronto fecundo, um marxismo isento de deformações. Neste sentido, Lukács afirma que

a derrota (...) do dogmatismo staliniano, o renascimento do método marxista, que seguirá a ela na medida em que se superem as deformações e lacunas dos últimos decênios e se restabeleça o método marxista em sua pureza e adequação à atualidade, será, simultaneamente, sem dúvida, também a vitória contra o neopositivismo (LUKÁCS, 1963, p. 11).

Ainda em maio de 1957, Lukács definia com clareza meridiana a sua peculiar posição diante da problemática da era stalinista:

Considero-me, no entanto, obrigado a dizer abertamente que não posso estar de acordo nem com aqueles que, transformando a obra de Stálin numa sensacional novela policial, tentam, com uma tal story e com a identificação acrítica de todo o trabalho de Stálin com a doutrina dos clássicos do marxismo, 
comprometer esta teoria e impor a sua revisão, nem com aqueles que já creem chegado o momento de uma nova canonização de Stálin, de sua plena reabilitação, malgrado um ou outro erro "isolado". (LUKÁCS, 1966b, p. 8)

Desta posição Lukács extraiu as consequências em sua atividade intelectual dos fins da década de [19]50, bem como nos anos 60. Em todas as suas obras posteriores a 1956 encontramos o cuidado crítico de aprofundá-la, assim como, nos prefácios e notas introdutórias a reedições de obras mais antigas, localizamos a preocupação em situá-las com relação à era stalinista. Aliás, cabe aqui uma notação que indica a serenidade de Lukács para com seu comportamento ante Stálin: reeditando seus trabalhos das décadas de 30 e 40 e do primeiro lustro da de 50, ele não revisou um só de seus comentários a respeito de Stálin. Fez questão fechada de que retornassem a público com seu conteúdo e sua forma originais, incluídas todas as referências elogiosas ao secretário-geral ${ }^{10}$, observando: "não perderei tempo com a questão das citações 'protocolares' de Stálin. Sempre tentei reduzir estas citações ao mínimo indispensável e limitar-me a reproduzir afirmações justas, frequentemente já conhecidas muito antes de Stálin" (LUKÁCS, 1966b, p. 8).

Lukács tinha fundadas razões para despreocupar-se: sempre fora, dentro e fora da URSS, um dos alvos prediletos do stalinismo. Não foi um mero acidente a sua prisão na URSS, em $1941^{11}$, assim como não foi gratuita a sistemática campanha de descrédito que lhe moveu, de 1949 a 19[5]1, o Ministério da Cultura magiar ${ }^{12}$. No entanto, a convicção de

10. Eis alguns exemplos destas citações: "O fascismo (...) quer apagar da consciência do povo alemão os nomes de Heine, Marx, Engels, Lênin e Stálin" (in Heinrich Heine como poeta nacional, 1935); "Marx, Engels, Lênin e Stálin indicaram-nos o caminho da verdadeira crítica" (in A estética de Hegel, 1951); "Somente Lênin e Stálin, e o Partido Bolchevique fundado e dirigido por eles, eram e são capazes de eliminar em todos os terrenos do marxismo as reticentes teorias do revisionismo" (in Prefácio a Contribuições à história da estética, 1952). Apenas a título de comparação, vejamos o que o grande Aragon (que, em 1953, considerava Stálin "o maior filósofo de todos os tempos") chegou a escrever, sem os constrangimentos de Lukács: "Le Grande Staline, le chef des peuples / Toi qui naitre l'homme / Toi qui fécondes la terre / Toi qui rajeunis les siècles / qui fais fleurir le printemps / Toi qui fais vibrer les cordes musicales / Toi splendeur de mon printemps, toi / Soleil reflété par le milliers de coeurs." (Apud PAPAIOANNOU, 1972, p. 414) Sobre o mecanismo psíquico que levou homens de talento a este gênero de "arte", cfr. as dolorosas observações de Jorge Semprun contidas em Autobiografia de Federico Sánchez (1977).

11. Mészáros (1972, p. 142) dá notícia da prisão de Lukács. A polícia política tentou, sem êxito, extrair-lhe uma confissão de que fora um agente trotskista. Recentemente, Michel Löwy encontrou nos arquivos de Lukács um texto que, segundo seu parecer, pode tratarse da autobiografia que o filósofo preparou para as autoridades soviéticas (cfr. LÚKÁCS, 1978; as observações de Löwy encontram-se à p. 28 e o texto está reproduzido nas pp. 147 ss).

12. É expressivo atentar para o fato de que a autocrítica que Lukács foi obrigado a fazer, em 1949 (e considerada insuficiente...), não foi apenas motivada pelos ataques a seu livro Literatura e democracia, mas ainda pelas ideias contidas em $O$ realismo russo na 
Lukács era mais profunda: esperava firmemente que, por baixo da obrigatória linguagem esópica de que se valera no período stalinista, as análises reconheceriam a crítica dissimulada e a manutenção de princípios antidogmáticos. Eis por que, sem maiores delongas, na sua obra posterior a 1956, ele transita da crítica oblíqua à denúncia aberta.

Esta denúncia se formula em função de três temáticas. A primeira centra-se nas relações entre Lênin e Stálin. Lukács esforça-se por mostrar que Stálin constitui mesmo o exemplo do dirigente antípoda a Lênin: enquanto este articulava uma integração orgânica e viva entre a teoria marxista e a práxis política, e, em razão disto, correlacionava corretamente a dependência das questões táticas aos objetivos estratégicos, Stálin notabilizava-se pelo seu taticismo, o soberano desprezo pela função regente da teoria, e pelo seu oportunismo, a visualização exclusiva de conjunturas singulares. Este é o núcleo do pensamento lukacsiano, cuja expressão literal é a seguinte: para Stálin, “a tática momentânea (...) era essencial. As injunções ditavam a estratégia e, em seguida, a estratégia era aplicada às perspectivas gerais do socialismo" (in HOLZ; KOFLER; ABENDROTH, 1969, p. 167). Particularizando:

a grande diferença entre Lênin e Stálin consiste exatamente no fato de que, na filosofia stalinista, se assim podemos chamá-la, o lugar principal é concedido às escolhas táticas práticopolíticas do momento, impondo-se uma degradação da teoria geral, que fica relegada a superestrutura, a embelezamento, e de fato não tem mais nenhuma influência sobre as decisões táticas (in: HOLZ; KOFLER; ABENDROTH, 1969, p. 154).

Esta degradação da teoria, a que Lukács faz referência, expressa-se basicamente na esquematização do marxismo: a sua vulgarização adequa a teoria ao papel rasteiro de apologia. Contudo, são gravíssimos os reflexos teóricos desta degradação, manifestando-se até na separação entre o materialismo dialético e o materialismo histórico. Como diz Lukács: "as tendências vulgarizadoras do marxismo, do período stalinista, manifestam-se também no fato de o materialismo dialético e o materialismo histórico terem sido tratados como ciências separadas a ponto de se formarem 'especialistas' de cada um deles” (LUKÁCS, 1966a, p. 14).

Denunciando a "estátua stalinista da infalibilidade”, Lukács encerra este nível da sua crítica asseverando a "ruptura prática e teórica que existe realmente entre Lênin e Stálin” (LUKÁCS, 1970a, p. 169) e insistindo em que "também historicamente (...) Stálin não representou, de modo algum, avaliara corretamente o valor "modelar" da literatura russa. 
nas grandes questões estratégicas, uma linha mais leninista que a de seus opositores" (LUKÁCS, 1970a, pp. 169-70)13.

Em segundo lugar, Lukács detém-se sobre a orientação cultural geral do período stalinista. Aqui, a crítica lukacsiana é tão sucinta quanto inclusiva: "No período de Stálin e Zdhanov, a história do pensamento foi sistematizada como se antes do marxismo existisse um determinado pensamento e, em seguida a um grande salto, ele tivesse sido completamente substituído pelo marxismo." (In: HOLZ; KOFLER; ABENDROTH, 1969, pp. 168-9) ${ }^{14}$ A esta postulação francamente dogmática - que, no extremo, leva ao sectarismo cultural e ao empobrecimento espiritual -, Lukács opõe a tradição leniniana: "O valor supremo do marxismo consiste substancialmente no fato de que ele se assenhoreou de todos os valores do bimilenar desenvolvimento europeu." (In: HOLZ; KOFLER; ABENDROTH, 1969, p. 169)

Finalmente - em função de seus prioritários interesses intelectuais -, Lukács aborda a questão da arte e da literatura.

Recusando com vigor o naturalismo do período stalinista - que conduzia, na literatura, ao "romantismo revolucionário" e à "literatura ilustrativa" -, Lukács, em páginas de fina argúcia15, desmascara a inépcia artística, a fragilidade estilística e o caráter descaradamente propagandístico que constituíram a maior parte da literatura produzida entre 1930 e 1950 na URSS. E, ao mesmo tempo, insiste na raiz destas mazelas: o imediatismo e o praticismo ideológicos patrocinados por Stálin, consequência do subjetivismo econômico que fundava a sua visão do mundo.

Esse naturalismo, oculto sob o rótulo de realismo socialista, fez que Lukács, sem abrir mão deste último conceito, o redefinisse duplamente: de um lado, restabelecendo as suas relações com o seu antecessor, o realismo crítico burguês e, de outro, posicionando-o na etapa pósstalinista: "atualmente, o realismo socialista tem por tarefa primordial levar até o fim a crítica da era stalinista” (LUKÁCS, 1970b, p. 14) ${ }^{16}$.

13. É interessante notar como o Lukács derradeiro, que se exprime assim, entra em discreta oposição consigo mesmo já depois da denúncia pública da era stalinista. Ver-seá, mais adiante, que ele considera correta a grande opção estratégica de Stálin pelo socialismo num só país. Poder-se-á objetar que, na verdade, Lukács considera a teoria do socialismo num só país já contida no último Lênin. De qualquer forma, é relevante notar o fato.

14. É curioso notar que as primeiras versões do pensamento althusseriano são compatíveis com a dogmática stalinista, precisamente por partirem de um pressuposto homólogo a este denunciado por Lukács (cfr. COUTINHO, 1972, esp. cap. V). Mais recentemente, Althusser não pôde evitar a tematização clara da crítica ao stalinismo (cfr., p. ex., ALTHUSSER, 1973, pp. 85 ss).

15. Cfr., p. ex., o ensaio O realismo crítico na sociedade socialista, última parte do já citado Realismo crítico hoje (LUKÁCS, 1969).

16. E, em seguida, Lukács aduz: "Evidentemente, esta é a missão essencial da ideologia socialista em seu conjunto". 
Lukács, porém, não se negou a um balanço específico da era stalinista como um todo. Logo após o XXII Congresso do PCUS, respondendo à convocação de Alberto Carocci, da revista italiana Nuovi Argumenti, ele redigiu a célebre Carta sobre o stalinismo ${ }^{17}$ - o documento mais centrado sobre o stalinismo que produziu.

Insistindo sempre no caráter de carta do texto - o que lhe retirava qualquer alternativa de procedimentos sistemáticos -, Lukács assinala que a expressão "culto da personalidade" nada esclarece sobre a era stalinista: evocando as propostas de pesquisa levantadas por Togliatti, ele afirma ser essencial, na análise do stalinismo, "a questão da gênese social do fenômeno". Sem pretender esgotar o tema, Lukács indica que, para o esclarecimento daquela gênese, "o ponto de partida só pode ser a situação interna e internacional em que se processou a Revolução proletária russa de 1917" [LUKÁCS, 1977, p. 2]. Diante desta situação, realmente dramática e agudizada, em nível de liderança, com a morte de Lênin, o filósofo húngaro observa que "Stálin se revelou um estadista notável (...). Sua enérgica defesa da nova teoria leninista quanto à possibilidade do socialismo em um só país, contra os ataques sobretudo de Trotsky, representou (...) a salvação da Revolução soviética" [LUKÁCS, 1977, p. 3]. Ou seja: "no que concerne aos problemas estratégicos então decisivos, Stálin teve plenamente razão contra Trotsky". Entretanto, nos anos seguintes, a posição de Stálin teria evoluído para coordenadas muito similares às defendidas por Trotsky: "aquilo que hoje consideramos despótico e antidemocrático, na época stalinista, tem ligações estratégicas bastante estreitas com as ideias de Trotsky" [LUKÁCS, 1977, p. 4].

Outrossim, sendo o "problema central, objetivamente consistente na obtenção de um ritmo acelerado de industrialização (...), com toda a probabilidade difícil de ser resolvido nos quadros da democracia proletária normal”, Stálin converteu-se em autêntico autocrata [LUKÁCS, 1977, p. 4]. Quanto a este processo, Lukács afirma que "a história precisará ser reexaminada a fundo pelos historiadores soviéticos, levando-se a cabo uma análise competente de todo o material existente e inclusive do material inédito até o presente". De fora do sistema de poder - ou seja, do lócus onde se situava o próprio Lukács -, “o que se podia constatar (...) era a liquidação sistemática das discussões internas no Partido, o acréscimo das medidas organizativas contra opositores e, em seguida, a passagem das medidas organizativas a procedimentos de caráter judicial e estataladministrativo" [LUKÁCS, 1977, p. 5].

17. Republicada recentemente, em tradução de Leandro Konder, no primeiro número de Temas de Ciências Humanas (LUKÁCS, 1977). As citações seguintes, sem referência, são extraídas desta versão. [Nesta edição, as referências bibliográficas foram acrescentadas entre colchetes - NE] 
Ora, a questão nuclear, no âmbito deste processo, é, para Lukács, "mostrar de que maneira Stálin, que, na década de [19]20, defendia com habilidade e inteligência a herança de Lênin, passou à oposição a este no que concerne a tantos problemas importantes" [LUKÁCS, 1977, p. 5]. Esta questão, ainda em aberto, segundo Lukács, pode ser verificada quando se analisam as grandes linhas da era stalinista.

Estas grandes linhas, para Lukács, são as seguintes:

$1 .^{\text {a }}$ - "a tendência staliniana é sempre a de abolir, quanto possível, todas as mediações, e a de instituir uma conexão imediata entre os fatos mais crus e as posições teóricas mais gerais” [LUKÁCS, 1977, p. 6];

2. ${ }^{\mathrm{a}}$ - a degradação da teoria - consequência da supressão das mediações -, que não se concretizava em sua verificabilidade prática, "mas, ao contrário, simplificando e vulgarizando os princípios segundo as exigências (comumente apenas presumidas) da prática" [LUKÁCS, 1977, p. 8];

$3 \cdot{ }^{\mathrm{a}}$ - a deformação subjetiva que se impôs ao conceito leninista de partidarismo: originalmente, "propaganda e agitação recebiam o seu material da ciência, da práxis cientificamente elaborada; Stálin inverteu esta relação. Para ele, em nome do partidarismo, a agitação torna-se o momento primário" [LUKÁCS, 1977, p. 10].

Da análise destas grandes linhas, Lukács conclui que,

no caso de Stálin, não se trata de erros particulares ou ocasionais (...) e sim de um falso sistema de ideias, gradualmente montado, um sistema cujos efeitos nocivos se fazem sentir tanto mais dolorosamente quanto menos as condições sociais atuais são semelhantes às condições em que apareceu o sistema stalinista e das quais o mesmo foi o reflexo deformado e deformante [LUKÁCS, 1977, p. 13].

Nesta conclusão está implícita a crítica ao neosstalinismo, que Lukács particulariza mais ao dizer que

os aparelhos culturais dos países socialistas ainda se acham, em ampla medida, nas mãos de discípulos dogmáticos de Stálin (que, no melhor dos casos, consentem em adaptar-se exteriormente à "novidade"). Boa parte dos novos quadros ainda é educada e formada no espírito stalinista. O sistema staliniano é um paraíso para todos os destituídos de talento, que não abrem mão dele com facilidade [LUKÁCS, 1977, p. 14].

Em outras oportunidades, Lukács tornou a patentear que o stalinismo, como sistema, não foi eliminado. Já evoquei a sua afirmação de que o que está ocorrendo é o desaparecimento do stalinismo sob a forma do stalinismo. Ele vai mais adiante: "Quanto à superação da época stalinista, estamos ainda em um período no qual os grandes erros do stalinismo vêm sendo eliminados sempre com os métodos stalinistas. Não 
chegamos, ainda, à superação destes métodos.” (In: HOLZ; KOFLER; ABENDROTH, 1969, pp. 154-5)

Ora, uma das razões ideológicas para a sobrevivência dos métodos stalinistas é, até hoje, como o reconheceu o próprio Lukács, a ausência de uma análise marxista profunda sobre a sua gênese social, bem como da sistemática da sua permanência. Consequentemente, Lukács - que não se julgava chamado a preencher esta lacuna, já que, juntamente com Togliatti, pensava "que esta tarefa competia, antes de tudo, aos soviéticos" - esclarecia conclusivamente que

$$
\begin{aligned}
& \text { somente quando as análises marxistas formularem (...) com } \\
& \text { relação a Stálin (...) um correto julgamento histórico, quando o } \\
& \text { sistema de seus erros estiver esclarecido e superado e } \\
& \text { convertido em passado histórico do marxismo atuante, somente } \\
& \text { então será possível pronunciar-se de modo adequado sobre o } \\
& \text { vivo e o morto do seu sistema (LUKÁCS, 1966b, p. 8). }
\end{aligned}
$$

Esta cautela de método e de juízo histórico não o impediu, como se viu, de estabelecer uma impiedosa crítica do conjunto de concepções da era stalinista - a partir de 1956. Cabe então indagar como Lukács comportou-se frente ao stalinismo enquanto Stálin estava vivo.

Em 1957, falando sobre isto, Lukács caracterizou seu trabalho intelectual sob Stálin como "combate espiritual de um partisan" (apud BAHR, 1972, p. 46). Importa, pois, verificar a significação desta guerrilha espiritual para o que, antes, faz-se necessário situar, ainda que rapidamente, a problemática cultural da era stalinista.

A problemática cultural da era stalinista só é minimamente compreensível se for articulada com o conjunto de concepções ideológicas desenvolvido pelo sistema patrocinado por Stálin.

Como sistema ideológico ${ }^{18}$, o stalinismo possui uma lógica específica que, pela sua estrutura, insere a produção cultural num âmbito muito determinado. A matriz axial do sistema é o voluntarismo burocrático ${ }^{19}$, isto é, a suposição - evidentemente não esclarecida nem explicitada e, pois, para seus agentes, a certeza - de que o esforço e a diligência da classe operária colimam os fins propostos pela direção

18. Parece-me fundamental insistir, ao contrário do que defende objetivamente uma longa tradição iniciada no XX Congresso da PCUS e que encontra em Ellenstein um continuador integral, que o fenômeno stalinista não é apenas um processo superestrutural. O fato de aqui se reduzir o stalinismo às suas mais simples determinações ideológicas, porém, justifica-se pelas restrições postas pelo nosso objeto de análise.

19. Que Lukács tematizou amplamente nas entrevistas coligidas em Conversando com Lukács. 
partidária. O caráter burocrático desta concepção deriva diretamente da própria maneira como a liderança política (por seu turno, no quadro da supressão da democracia socialista, legitimada tão-somente por uma fidelidade incondicional ao poder) direciona a vida social: pela via administrativa. Mas a tônica dessa matriz é melhor expressa pela sua substantividade: é o seu voluntarismo que mais adequadamente a dimensiona. Com efeito, o traço clássico do stalinismo - resultante da supressão ideal das mediações, apontada por Lukács - é o menosprezo pelas conexões entre as condições objetivas nas quais se realiza a prática social e a interioridade humana que anima (e é animada) por esta prática; vale dizer: são suprimidas as mediações entre o sujeito e o objeto da prática social. Esta supressão responde pelo movimento pendular da ideologia da era stalinista: ora amarrada ao mais positivista dos objetivismos, com o culto das "condições objetivas", ora presa ao mais agudo dos subjetivismos, com a glorificação das ilimitadas possibilidades da individualidade "operária”. Outrossim, decorre desse movimento entre extremos que se complementam sem se superar a peculiar estrutura da ideologia da era stalinista, inteiramente dirigida para a justificação imediata das diretivas implementadas pelos núcleos dirigentes; trata-se, pois, de uma ideologia puramente instrumental e manipuladora, centrada prioritariamente em torno de exigências apologéticas.

É mais ou menos evidente, assim, que a produção cultural, no interior de uma moldura como esta, tenha o seu espaço de desenvolvimento e funcionalidade rigidamente delimitado: cabe-lhe edulcorar a realidade. Seu conteúdo de crítica do presente é-lhe retirado em nome da construção do futuro: a avaliação do passado, que obrigatoriamente realiza a cada passo, só lhe é permitida enquanto prova de que o presente - este presente - se valida por ela. A problemática especificamente cultural que emerge de um sistema como o da autocracia stalinista, portanto e necessariamente, é a problemática do dogmatismo.

O dogmatismo distingue-se da ortodoxia. Esta implica, exclusivamente, a adesão crítico-científica e criadora a determinados princípios metodológicos, enquanto o dogmatismo envolve o arbitrário e incondicional compromissamento com resultados científicos parciais ou proposições ideológicas singulares. Lucien Sève indicou justamente a essência do dogmatismo, dizendo-o “o arbitrário de um pensamento desligado da vida", que se pode notabilizar "tanto por sua aparente receptividade à renovação criadora quanto por sua aparente firmeza $e$ intransigência quanto aos velhos princípios" (SÈVE, 1965, p. 245). O raciocínio de Sève é correto: o dogmatismo não significa simplesmente a fidelidade a ideias antigas ou o repúdio a novas conquistas. Ao contrário: 
ele pode manifestar-se na sede de novidades tanto como na dependência do passado. Mais exatamente, nas palavras de Sève:

o dogmatismo não se manifesta apenas na repugnância ou na incapacidade em revisar o que deve ser revisto, em função dos ensinamentos da experiência - aspecto bem conhecido -, mas também - aspecto menos conhecido talvez - na revisão arbitrária do que não tem nenhuma razão válida para ser revisto. O dogmatismo consiste em fixar, mas consiste também em liquidar (SÈVE, 1965, p. 245).

Nesta ótica, a problemática cultural da era stalinista se nos revela a problemática do dogmatismo por excelência. Porque, a par de esclerosar princípios válidos (as célebres "leis fundamentais" que Stálin e seus ideólogos descobriram) e instituir novidades espúrias (como a tese staliniana da agudização das lutas de classes no socialismo), o sistema ideológico da era stalinista conjugou o seu dogmatismo teórico com um difuso liquidacionismo, corporificação de concepções rasteiramente apologéticas, as suas exigências imanentes conduziram a uma produção cultural articulada sobre uma inorgânica mescla de objetivismo e subjetivismo, da qual a concreta realidade sócio-histórica era banida ou adulterada segundo a inspiração administrativa de decretos vindos do alto.

Historicamente, a constituição de uma política cultural dogmática explícita tem seu momento de arranque quando, reduzida pela coação política a baixíssimos níveis a efervescência criadora desenvolvida durante os primeiros momentos da democracia socialista ${ }^{20}$, realiza-se, em agosto de 1934, o I Congresso dos Escritores Soviéticos. A peça básica dessa política reside no discurso então pronunciado por Máximo Gorki (GORKI; ZDHANOV, 1968) - e este não é o menor paradoxo com que nos defrontamos na análise da evolução cultural soviética sob Stálin: o grande artista Gorki, episodicamente como teórico da literatura, abriu o caminho para a política cultural stalinista ${ }^{21}$.

A argumentação desenvolvida por Gorki, na sua alocução àquele Congresso, é extremamente pobre e dogmática. Constatando que um novo padrão societário surge com o socialismo, Gorki sustenta a tese de que a

20. Em outubro de 1931, a Associação Russa de Escritores Proletários (RAPP) foi dissolvida e, na esteira da repressão, nada mais restou de seus grupamentos (LEF/Frente de Esquerda e LITFront/Frente Literária). Em meados da década de 30, centros como a Associação Pan-Russa de Escritores Proletários (VOAPP) ou o Teatro da Juventude Operária (TRAM) eram já remotas lembranças do passado.

21. É evidente que isto em nada compromete a obra literária de Gorki. E, seja dito de passagem, nem todos concordam em que as teses gorkianas expandidas naquele Congresso estejam na base do dogmatismo posterior do stalinismo (é o caso, p. ex., de Francisco Posada, em seu belo livro Lukács, Brecht e a situação atual do realismo socialista [POSADA, 1970]). De minha parte, alinho-me com Leandro Konder, para quem a estreiteza das colocações teóricas de Gorki "serviu para escorar os esforços de uma direção burocrática no sentido de enfeudar a arte às exigências imediatas da propaganda política do Partido" (KONDER, 1967, p. 89). 
ele corresponde um novo tipo de arte literária - o realismo socialista. É indiscutível que, para a estética marxista, a introdução deste novo conceito significou um passo adiante. No entanto, tal como Gorki o formula, o realismo socialista tende a converter-se num neonaturalismo bem conveniente ao prosaísmo burocrático. O autor de $A$ mãe embasa sua tese a partir da seguinte observação: "Temos a esperança, muito fundamentada, de que quando toda a história da cultura humana for escrita por marxistas, chegaremos à conclusão de que a missão da burguesia no campo da cultura foi exagerada." (GORKI in GORKI; ZDHANOV, 1968, p. 19)

Uma assertiva como esta - que é visceralmente dogmática porquanto inova arbitrariamente todas as concepções dos "clássicos" do marxismo ${ }^{22}$ - tem como consequência a instauração de um hiato entre o realismo crítico burguês e o realismo socialista e, sobretudo, pode legitimar uma visão estreitamente sectária da arte literária. Aliás, foi neste sentido que Zdhanov - o ideólogo da cultura da era stalinista no imediato pós-guerra - a desenvolveu:

Os imperialistas e seus lacaios ideológicos, seus escritores e publicistas (...) se esforçam (...) para caluniar nosso país (...), para difamar o socialismo. Nestas condições a tarefa da literatura soviética não é apenas responder (...) a esta miserável calúnia (...), mas também a de fustigar e atacar audaciosamente a cultura burguesa que se acha em estado de marasmo e corrupção. (ZDHANOV in: GORKI; ZDHANOV, 1968, p. 96)

A cultura burguesa, segundo Zdhanov, tem "seu fundamento moral (...) putrefato (...) porque foi colocada a serviço da propriedade capitalista privada, a serviço dos egoístas interesses das camadas burguesas mais altas da sociedade" (in: GORKI; ZDHANOV, 1968, p. 96).

A avaliação que Gorki opera do realismo crítico burguês, de fato, é lamentável: "Sem querer negar o vasto e enorme trabalho desempenhado pelo realismo crítico, cujas aquisições formais e nas letras nós apreciamos altamente, devemos compreender que tal realismo só nos é indispensável para aclarar as sobrevivências no passado, para lutar contra elas e eliminálas.” (Apud KONDER, 1967, pp. 87-8) Reduzindo a herança cultural do realismo burguês a conquistas de técnica literária e a índice documental de situações sociais que devem ser superadas, vale dizer, atribuindo-lhe o valor de mero testemunho histórico, Gorki, na verdade, despreza aquele rico manancial. O caminho está aberto para a formulação de Révai, discípulo dos métodos zdhanovistas e inquisidor de Lukács: "Nós construímos o socialismo (...); nós devemos então nos inspirar, em primeiro lugar e de modo decisivo, na cultura de um país onde o

22. Leandro Konder, na obra citada, mostrou claramente como esta tese se choca, de modo frontal, com as ideias particularmente defendidas por Engels. 
socialismo já está edificado. (...) A cultura soviética serve como modelo e mestre-escola [sic] à nossa nova cultura socialista.” (RÉVAI, 1957, p. 795)

Para o realismo socialista, Gorki propõe uma tarefa muito clara: "O realismo socialista afirma a existência como atividade, como criação. Seu objetivo primordial consiste em desenvolver os dotes do homem (...) em prol da sua saúde e sua longevidade.” (In: GORKI; ZDHANOV, 1968, pp. 55-6) Para tanto, "o herói de nossos livros deve ser o trabalho personificante do operário (...), o homem que (...) organiza o trabalho, tornando-o fácil, mais fecundo, elevando-o à altura da arte" (in: GORKI; ZDHANOV, 1968, p. 44). Com estas premissas estão perfeitamente sincronizadas as determinações de Zdhanov:

Nós nos transformamos e nos desenvolvemos ao compasso das grandes modificações que alteraram radicalmente a face do nosso país. Exibir estas novas e elevadas qualidades do povo soviético... - eis a tarefa de todo escritor soviético consciente. (...) Nosso povo deve ser um povo culto e de alto nível ideológico, com elevadas exigências e gostos culturais e morais. Com este fim, nossa literatura, nossos periódicos, não devem ficar à margem das tarefas da vida contemporânea, mas devem ajudar o Partido e o povo (...). O povo, o estado, o Partido querem que a literatura não se afaste da vida contemporânea. (In: GORKI; ZDHANOV, 1968, pp. 97; 99)

Quanto ao papel social dos artistas, Gorki - retomando, en passant, a horrorosa caracterização staliniana do escritor como "engenheiro de almas" - atribui-lhes "o papel de juízes do universo", oferecendo-lhes "o direito de colaborar diretamente na transformação do mundo" (in: GORKI; ZDHANOV, 1968, pp. 56). Zdhanov, com a sua notável ligeireza, não perdeu tempo e deduziu que "os escritores soviéticos devem ajudar o povo, o estado, o partido, educando nossa juventude na plenitude de espírito e na autoconfiança para enfrentar quaisquer dificuldades" (in: GORKI; ZDHANOV, 1968, p. 98). E Révai, por seu turno, inferiu que o artista "não tem o direito de escrever o que quiser":

o gosto e o julgamento do escritor podem ser contrários ao julgamento e aos interesses do povo, do estado ou do partido. E não são o estado e o povo que devem adaptar-se ao seu gosto e ao seu julgamento: é o escritor que deve, pelo trabalho e pelo estudo, tornar-se solidário com os interesses da edificação do socialismo (RÉVAI, 1956/7, pp. 799-800) ${ }^{23}$.

Há que ficar patente que Gorki não participou de nenhum procedimento burocrático-administrativo da política-cultural da era

23. É importante observar que Révai, ao contrário do que estas citações podem sugerir, era um intelectual cultivado. Ernst Fischer comentou, certa feita, sem ironia e até pesaroso, o dilaceramento que o stalinismo produziu na personalidade de Révai: quando se investia como porta-voz do Partido, as suas colocações estreitas, sectárias e burocratizantes colidiam pateticamente com seus pontos de vida pessoais. 
stalinista $^{24}$. E as inferências catastróficas extraídas do seu pronunciamento de 1934 por todos os Zdhanov do stalinismo o foram à sua revelia. Realmente, a política cultural dogmática só teria sua explicitação completada com a ascensão de Zdhanov à condição de principal ideólogo do sistema ${ }^{25}$, onde, diga-se de passagem, ele apenas organizou as normas que desde pouco antes da II Guerra já regiam o enquadramento dos artistas.

Com efeito, desde o segundo lustro dos anos [19]30, o comportamento do aparelho stalinista diante das manifestações culturais já as compelia ao enquadramento, ora situado como neonaturalismo decorrência da predominância do objetivismo ideológico -, ora focado como romantismo revolucionário - componente do voluntarismo subjetivista do sistema. O romantismo revolucionário não excluía o neonaturalismo: na medida em que o realismo socialista era reduzido à ilustração de proposições vindas do alto da direção partidária, ambos se implicavam mutuamente: à superficialidade maçante do neonaturalismo, o romantismo revolucionário acrescentava dimensões "poéticas".

No domínio filosófico, todavia, o dogmatismo, que se estendia desde as vésperas da II Guerra, quando Stálin decretou que a grande filosofia alemã era a afirmação do obscurantismo (Hegel passou a ser considerado o "filósofo da reação prussiana").Viu-se realmente impulsionado por Zdhanov, na sua celebre alocução A frente ideológica e a filosofia, pronunciada em $1947^{26}$.

Criticando asperamente a obra do acadêmico Alexandrov, um manual de história da filosofia, Zdhanov estabeleceu, com assombrosa clareza, os quatro postulados básicos da política da era stalinista no terreno da filosofia:

$1^{0}$. - a ruptura do marxismo com toda a herança filosófica anterior: "a filosofia marxista surge como a negação mais completa e categórica de todas as filosofias anteriores" (in: GORKI; ZDHANOV, 1968, p. 12);

$2^{\circ}$. - a função da filosofia como legitimação teórica do status quo: "quando se fala de frente filosófica surge no mesmo instante a ideia de um destacamento organizado de filósofos combatentes (...) que armam os trabalhadores da sociedade socialista com a consciência

\footnotetext{
${ }^{24}$. O grande escritor, como se sabe, morreu em 1936.

25. Zdhanov não exerceu por muito tempo a função de censor-mor: morreu no verão de 1948, mas não lhe faltaram sucessores zelosos, assim como ele mesmo fora um zeloso continuador do que já vinha de antes.

26. Esta alocução está publicada em Literatura, filosofia, marxismo, já citado. Nela, Zdhanov apenas esclarecia normativamente o que já se exigia da filosofia. Mas não se pode esquecer o papel que, desde antes, as obras de Stálin - pelo seu próprio conteúdo desempenharam no abastardamento da filosofia.
} 
de estarem no caminho certo e com a confiança (...) na vitória final da nossa causa" (in: GORKI; ZDHANOV, 1968, p. 131);

$3^{\circ}$. A mecânica separação entre o materialismo dialético e o materialismo histórico, derivando-se o "caráter científico da filosofia" das "conquistas das ciências naturais" (in: GORKI; ZDHANOV, 1968, p. 125);

$4^{\circ}$. O voluntarismo subjetivista como força de desenvolvimento da filosofia: "a causa deste atraso na frente filosófica não está ligada (...) a nenhuma condição objetiva. (...) [As causas] devem ser buscadas no domínio subjetivo (...) já é tempo de impulsar mais audazmente a teoria da sociedade soviética e seu estado, a teoria das ciências naturais contemporâneas, a ética e a estética. É necessário extirpar uma covardia estranha ao bolchevismo" (in: GORKI; ZDHANOV, 1968, pp. 132; 135).

Foi no interior desses parâmetros culturais e ideológicos que Lukács teve de trabalhar.

\section{4}

O posicionamento de Lukács ante as formulações derivadas da dogmática da era stalinista não deve ser investigado a partir de questões singulares. Antes, deve ser conduzido a partir do exame da concepção geral afirmada por Lukács e pelo aparelho da era stalinista; só então os problemas isolados poderão ser convenientemente equacionados. Pois bem: desde 1931 - precisamente o período da "grande transformação" referida por Deutscher - Lukács ${ }^{27}$ afirma reiteradamente o oposto das formulações dogmáticas ${ }^{28}$.

À concepção stalinista-zdhanovista do marxismo como "absoluta originalidade", ele, na esteira de Lênin, opõe a compreensão do marxismo como produto cultural que sintetiza e supera a quintessência do pensamento ocidental. Eis por que, ainda em 1939, quando a "novidade" do socialismo era coroada pela vigência da constituição stalinista de 1936 e pelos métodos dos "expurgos" do momento, Lukács podia escrever: "a plena realização, a culminação da individualidade na sociedade socialista

27. É sempre bom lembrar que, nesta época, Lukács era um emigrado em Moscou. Mais precisamente: um exilado político, submetido à severa vigilância da polícia política, que não lhe perdoava o "esquerdismo" dos inícios da década de 20.

28. Ainda que, nestas afirmações e por motivos mais que óbvios, Lukács envolva sempre, elogiosamente, o nome de Stálin. Numa entrevista concedida a P. Anderson em 1969, e publicada na New Left Review (1971), Lukács diz o seguinte sobre os seus ensaios editados na Literarny Kritik: "Escrevi numerosos ensaios nesta revista e cada um deles comportava pelo menos três citações de Stálin - era uma necessidade insuperável na Rússia desse tempo - e cada um era diretamente dirigido contra o dogmatismo stalinista”. Esta entrevista está republicada em G. Lukács, Littérature, philosophie, marxisme (1978). 
não é nada de absolutamente novo, mas o triunfo de esforços centenários, até milenares, dos melhores representantes do gênero humano" (LUKÁCS, Gottfried Keller in: LUKÁCS, 1970c, p. 201). Como se vê, o pensador húngaro não contradiz a dogmática emergente apenas no terreno do marxismo como teoria, mas, ainda, no campo prático-concreto da efetivação do socialismo. $\mathrm{E}$, seis anos depois, na maré montante do obscurantismo do pós-guerra, ele retomava a discussão, esclarecendo que

o princípio básico da concepção materialista da história, segundo o qual a liberação real e definitiva da humanidade com relação aos deformantes efeitos das sociedades de classes só pode ser alcançada com o socialismo, não significa uma contraposição rígida, adialética e esquemática, uma sumária recusa da cultura das sociedades de classes (...). É verdade que a história real da humanidade vai começar com o socialismo. Mas a pré-história que leva a este socialismo é um elemento integrante do nascimento do socialismo. $E$ os traumas deste caminho não podem ser indiferentes para os autênticos "partidários do humanismo marxista" (LUKÁCS, Introducción a los escritos estéticos de Marx y Engels in: LUKÁCS, 1966b, p. 260, grifos meus).

Esta passagem contém a chave que elucida o posicionamento lukacsiano: às vésperas da ascensão de Zdhanov ao estatuto real de censormor, ele problematiza quer a filosofia marxista como " a negação mais completa e categórica" das precedentes - ao, implicitamente, inserir a relevância das formações culturais anteriores à emergência do socialismo -, quer o próprio trânsito ao socialismo - sugerindo que seus ônus o afetam sobremaneira.

É liminarmente óbvia a oposição entre ambas as concepções: de um lado, a dogmática, tomando o socialismo como ruptura teórico-prática absoluta com o passado, e legitimando-o pela sua própria existência; doutro, a lukacsiana, aprendendo-o como superação do passado e pondo em questão as vias que conduzem à sua existência.

No entanto, esta oposição só pôde efetivar-se enquanto "combate espiritual de um partisan”. Faltavam a Lukács as mínimas condições objetivas para levá-la a cabo abertamente; não apenas há que considerar a (fundamental, no caso) impossibilidade física, mas também, como o próprio filósofo lembrou, a

impossibilidade moral: a URSS combatia decisivamente o fascismo. Um comunista firme somente podia dizer: "Certo ou errado, é meu partido”. Às ações deste partido, conduzido por Stálin e no seio do qual muitos pensavam como eu, devíamonos associar, entrar no combate, ser incondicionalmente solidários com ele e manter, apesar de tudo e contra tudo, esta solidariedade (apud BAHR, 1972, p. 46). 
A tática do partisan, assim, torna-se inteligível nas questões particulares. Enquanto a dogmática apresentava a cultura alemã excluídos, naturalmente, Marx, Engels e os comunistas - como nazista avant la lettre, Lukács empreendia percucientes análises dos fautores daquela cultura, convencido de que "a nossa tarefa é apenas deixar que soe a voz clara e aberta da realidade histórica” (LUKÁCS, Georg Büchner in: LUKÁCS, 1970c, p. 91).

Insistindo na indispensabilidade da conservação da herança cultural - tema que lhe é caro desde as suas polêmicas em Die Linkskurve (e ao qual adiante voltaremos) -, Lukács opõe-se ao antigermanismo oportunista da dogmática, que, por razões chãmente propagandísticas, a ele reconduzia os sentimentos antifascistas; assim, escrevia em 1939: "foi desenvolvendo-se na Alemanha a filosofia clássica de Leibniz a Hegel, à qual devemos a expressão, em alto nível científico, das leis gerais da contradição entre o ser e a consciência, contradição profundamente relacionada, embora às vezes ocultamente, à descoberta das contradições da sociedade burguesa" (LUKÁCS, Gottfried Keller in: LUKÁCS, 1970c, p. 162). Precisamente no tempo em que Hegel era "o filósofo da reação prussiana", 1940, Lukács insistia em que "o Fausto de Goethe e a Fenomenologia do Espírito de Hegel são as duas produções artísticas e intelectuais maiores do período clássico na Alemanha” (LUKÁCS, Estudios sobre el Fausto in: LUKÁCS, 1970c, p. 364) - e não é casual que, em plena vigência do zdhanovismo, ele tenha publicado $O$ jovem Hegel $e$ os problemas da sociedade capitalista, obra monumental em que, concreta e particularmente, recusam-se os quatro princípios enunciados por Zdhanov para o tratamento da questão filosófica. Por outro lado, pouco antes, em julho de 1947, Lukács concluía os estudos de Existencialismo ou marxismo?, em que intentava uma aproximação séria à crítica radical das correntes existencialistas $^{29}$.

A crítica implícita da dogmática filosófica, formula-a ainda Lukács no seu contundente e polêmico $A$ destruição da razão, concluído em fins de 1952. Contra o voluntarismo subjetivista apregoado pelo establishment, ele afirma que "é o desenvolvimento das forças produtivas, o desenvolvimento social, o desenvolvimento das lutas de classes que colocam os problemas à filosofia e assinalam as vias para a sua solução" (LUKÁCS, 1968, p. 3). A concepção zdhanovista de "um destacamento organizado de filósofos combatentes", preocupados em armar "os trabalhadores da sociedade socialista”, Lukács mostra que corresponde à

29. É importante ressaltar que se trata de uma aproximação séria - e para que se compreenda esta cautela, basta que nos lembremos de que, mais ou menos na mesma época, Henri Lefebvre escrevia que Sartre era um autor que fazia "la métaphysique de la merde" (apud KONDER, 1967, p. 159). Existencialismo ou marxismo? foi recentemente reeditado no Brasil (SARTRE, 1979). 
minimização das críticas imanentes, o que "conduz necessariamente a uma atitude sectária em filosofia” (LUKÁCS, 1968, p. 5).

Os detalhes da guerrilha intelectual lukacsiana, contudo, são mais numerosos no campo de trabalho a que ele se dedicou mais intensivamente durante a era stalinista, o da teoria e da crítica literária ${ }^{30}$.

Seus procedimentos, também aqui, opõem-se àqueles que, desde o Congresso de 1934, converteram-se na doutrina oficial da dogmática. Segundo Lukács, "se o realismo socialista é a superação real de todas as tendências mesquinhas e empobrecedoras da evolução burguesa, ao mesmo tempo implica uma conservação de todas as tendências progressistas promovidas por esta via humana” (LUKÁCS, 1970c, p. 13). Recusada, assim, no essencial, a proposta gorkiana, Lukács vai mais longe:

por muito que, em toda evolução literária, o realismo socialista signifique algo eminentemente novo e revalorizador, e por muito que corresponda a um salto qualitativo (embora, é claro, a configuração artística concreta deste salto não seja possível senão ao cabo de um longo processo, cheio de problemas), seu ponto de partida é, necessariamente, toda a linha progressista central da arte e do país em questão (e da literatura universal, em linhas gerais) (LUKÁCS, 1970c, p. 13).

Contra a avalanche de romances e novelas "patrióticos" e "ideológicos" que cresceu no correr da década de [19]30, festejados e estimulados pela função "pedagógica" (na verdade, grosseiramente propagandística) que a dogmática reservava e impunha à literatura, Lukács afirmava, resolutamente, que "a antipatia justificada (...) contra o formalismo corrompido de l'art pour l'art burguesa se converte frequentemente numa luta contra a especificidade da configuração artística em geral. Produz-se com frequência a tendência de rebaixar a arte ao nível de uma agitação cotidiana direta" (LUKÁCS, Arte y verdad objetiva in: 1966c, p. 48). A crítica lukacsiana atinge a dogmática quer no plano da apreciação da obra como elaboração formal peculiar, quer no plano das relações entre ideologia e arte. Assim é que Lukács - que, nesta época, juntamente com M. Lifschitz e outros, combatia o sociologismo na crítica literária soviética e marxista em geral ${ }^{31}$, proclama que "o maior perigo consiste numa concepção muito direta da relação entre ideologia e criação artística" (LUKÁCS, Marxisme ou proudhnisme en histoire littéraire? in: 1974, p. 237) e recorda que, desde 1840, “contra a expressão direta de ideias políticas, Marx e Engels realizam um combate artístico, ideológico e político em defesa da figuração artística da realidade com todas as suas contradições" (LUKÁCS, Pourquoi Marx et Engels ont-ils

${ }^{30}$. Sobre este ponto, é útil recorrer à bela introdução de Claude Prevost ao volume póstumo de Lukács (1974).

${ }^{31}$. Ver, quanto a este ponto, a já citada introdução de C. Prévost e boa parte dos trabalhos reunidos em Écrits de Moscu (LUKÁCS, 1974). 
critiqué l'idéologie libérale? in: 1974, p. 176). Mas o crivo analítico de Lukács assinala que o imediatismo da dogmática, imediatismo próprio da defesa de uma arte de tendência - que ele repudiou, já nos inícios dos anos 30, em prol do partidarismo - , afeta a obra de arte como realidade também formal, uma vez que "a forma artística nunca é uma simples imagem mecânica da vida social. É certo que ela emerge enquanto reflexo de tendências sociais, mas, neste âmbito, ela possui sua própria dinâmica, sua própria orientação" (LUKÁCS, Tendência o partidismo? in: 1968c).

Uma crítica com tais características deriva, naturalmente, de uma atitude de fundo em face do quadro político-social maior que implementa a "arte de tendência”. Esta atitude de fundo é translúcida num dos escritos lukacsianos mais felizes: Tribuno do povo ou burocrata?, de 1940, páginas de inequívoca tomada de posição acerca da vida social na era stalinista. Tomando como pretexto a obra leniniana Que fazer? (1902) - que, com alguma ironia referida ao presente, ele considera "a primeira reação de princípio ao oportunismo no plano internacional” -, Lukács assinala contundentemente que "a burocracia é um corpo estranho no socialismo" (LUKÁCS, 1968b, p. 151) e afirma sem reticências:

deveremos concentrar nossa atenção no significado social assumido na URSS pelo fenômeno do burocratismo. E, enquanto não pudermos afirmar que a burocracia desapareceu da realidade social sem deixar marcas, seremos obrigados a examinar cuidadosamente e a combater implacavelmente suas repercussões nos mais variados campos, entre os quais os da literatura e da arte (LUKÁCS, 1968b, p. 150).

Note-se: entre os quais os da literatura e da arte... Maior clareza impossível.

É difícil imaginar uma atitude crítica mais profunda do que esta a partir do enquadramento da emigração política sob a coação stalinista. Lukács, porém, estabeleceu a sua guerrilha contra a dogmática até o limite mais extremo; já se viu quais as funções o sistema atribuía à literatura; vejamos agora a apreciação lukacsiana dessa literatura. Em 1936, Lukács observava: "na maioria desses romances ${ }^{32}$, mal se iniciou a leitura, já se sabe de todo o resto: numa fábrica trabalham inimigos do povo; reina a enorme confusão; finalmente, a célula do partido ou a GPU descobre os elementos antissociais, e a produção floresce" (LUKÁCS, Narrar o describir? in 1966c, p. 210) e, num ensaio do mesmo ano, indagando-se sobre a apologética literária: "qual é o núcleo de toda apologética? A tendência que consiste em deter-se na superfície dos fenômenos e em eliminar mentalmente do mundo os problemas mais profundos, essenciais e decisivos" (LUKÁCS, La fisionomía intelectual de las figuras artísticas in: 1966c, p. 139). Como Lukács mostra, é este esquematismo que responde

${ }^{32}$. Trata-se de romances realistas socialistas da década de 30. 
sempre pelo final falsamente otimista - autêntico similar do happy end burguês decadente - de um número esmagador de obras do realismo socialista33.

Lukács foi até o limite mais extremo, protegendo-se apenas sob a tática de um Esopo moderno - como se comprova na avaliação que, em 1951, fez das teses de Stálin sobre linguística numa conferência da Academia Húngara de Ciências 34 .

Em junho de 1950, por meio do Pravda, Stálin publicou um longo artigo sobre a teoria linguística de Marx35, que postulava a língua como superestrutura social; no seu texto Stálin sustentava o oposto36. Desnecessário é acrescentar que as ideias de Marx tornaram-se malditas da noite pro dia. Não me interessa discutir o núcleo da argumentação staliniana; só vale a pena observar em que contexto teórico ela se inseria. Este contexto aparece na meridiana formulação do secretário-geral:

a superestrutura é o produto de uma época em cujo decurso subsiste e opera uma determinada base econômica. Por isso, a superestrutura não dura mais que a base, mas é eliminada e desaparece ao eliminar-se e desaparecer a base. (...) Desde a morte de Púchkin correram mais de 100 anos. Neste período se eliminaram da Rússia a ordem feudal e a ordem capitalista, e surgiu uma terceira, a socialista. Consequentemente, foram eliminadas duas bases junto com as suas superestruturas. Mas, se considerarmos a língua russa, vemos que ela não experimentou neste tempo nenhuma transformação radical, diferenciando-se muito pouco, estruturalmente, da língua de Púchkin. (1972, p. 7, grifos meus)

Como se vê, um extraordinário exemplo de simplismo e mecanicismo. Lukács "que, à época, estava submetido a dura pressão ideológica”, não concedeu: submeteu o contexto teórico sobre o qual Stálin se movia a uma crítica que, mesmo elíptica, é evidente. Ele situa as afirmações de Stálin no âmbito da arte e da literatura e, à guisa de uma interpretação, polemiza com secretário-geral37.

A “interpretação" começa com as citações protocolares: as teses de Stálin são consideradas "históricas" etc. Mas a polêmica penetra todos os

\footnotetext{
33. Cf. a segunda parte do seu artigo sobre Terras desbravadas, de M. Sholokhov, publicado em 1951 e reproduzindo em 1968c, pp. 467 ss.

34 . Esta conferência, intitulada Arte e literatura como superestrutura, está reproduzida em 1966b, pp. 487 ss.

35. Sobre N. J. Marr (1864-1934), o leitor interessado encontra breve referência em G. Mounin (1968, pp. $32 \mathrm{ss})$

${ }^{36}$. O texto staliniano foi, logo depois, publicado em livro. Uma edição acessível deste material é a tradução inglesa (STÁLIN, 1972). Esta edição contém, além do ensaio de Stálin, outros materiais sobre o desdobrar da polêmica então iniciada.

${ }^{37}$. Seis anos depois, no prólogo que preparou para a edição italiana de Contribuição à história da estética, Lukács comentava: "foi uma sorte que meu compulsório mimetismo teórico obtivesse êxito, e que a crítica oculta não fosse reconhecida como tal" (cfr. 1966b, p. 8).
} 
passos da reflexão lukacsiana: posto que a língua não seja superestrutura, a literatura, que se vale dela, o é; mas, afirmando o caráter superestrutural da produção artística, Lukács combate o mecanicismo pré-marxista que conduz ao e a que conduz o simplório raciocínio de Stálin - "podemos, pois, afirmar que, quando a velha base perece, a maior parte da velha superestrutura literária e artística perece" (LUKÁCS, 1966b, p. 508). Enquanto Stálin afirma o perecimento de toda a superestrutura cultural, Lukács fala da maior parte dela. Mas não é aí que reside o fulcro da crítica; na concepção staliniana, a superestrutura é epifenômeno da base; Lukács retruca: "uma superestrutura não apenas reflete a realidade, mas também toma ativa posição a favor ou contra a velha ou a nova base" (LUKÁCS, 1966b, p. 505). E mais: "no curso da história, até hoje, em todas as épocas, desempenharam papel de importância obras literárias e artísticas que foram, inicialmente, superestrutura em épocas remotas" (LUKÁCS, 1966b, p. 508).

A refutação a Stálin - por detrás de fórmulas compulsoriamente usadas, como: "as tradições do marxismo concretizam-se e desenvolvemse com as afirmações de Stálin” (LUKÁCS, 1966b, p. 510) - é indiscutível; só mesmo o descuido analítico não percebe que Lukács corrige o secretário-geral em dois pontos fundamentais e decisivos. Primeiro: enquanto Stálin defende a ideia de que a superestrutura serve a uma só base, Lukács mostra que isso não é exato, uma superestrutura também pode desservir a essa base; segundo: enquanto, para Stálin, a eliminação da base corresponde à eliminação de toda a superestrutura, Lukács prova que o desaparecimento da base não implica o automático desaparecimento de toda a superestrutura.

Entre Lukács e a dogmática, há, realmente, uma oposição de princípios.

Indicada, ainda que somente em grandes traços, a oposição de princípio que Lukács sustentou contra as linhas culturais básicas da era stalinista, a crítica permaneceria insuficiente se não colocasse de manifesto, em traços igualmente breves, aquilo que responde pela força e pela fraqueza dessa oposição, ou seja: o fato de ela ser interior à própria problemática global de que a era stalinista deriva.

Com efeito, assim como é pura mistificação associar o pensamento de Lukács, sobretudo após a crise capitalista de 1929, à dogmática identificando-o ou não inteiramente com ela -, também é exercício condenado à esterilidade apresentá-lo como flora quimicamente indene dos descaminhos do socialismo, refratário à era stalinista por obra e graça 
de alguma redoma misteriosa ${ }^{38}$. O simplismo frequentemente oportunista de uma argumentação não é superável com a ingenuidade bemintencionada da outra. $\mathrm{Na}$ verdade, a era stalinista, essa brutal deformação, teórica e prática, do pensamento e da vida do movimento operário revolucionário, esse desvio (se se quiser) ${ }^{39}$, em suma, não é um acessório que se lance pela porta sem mais aquela40; é uma hipoteca real que diz respeito a todo pensador de boa cepa que se comprometeu com a transformação social revolucionária, como Lukács o fez - afinal, por três décadas, foi o seu marco referencial, o seu terreno de luta, seu horizonte de combate. Ora, a oposição lukacsiana desenvolveu-se a partir do mesmo plano político macroscópico sobre o qual assentou a possibilidade da constituição da era stalinista: precisamente a prática política resultante da situação de fato que foi legitimada no nível ideológico pela teoria do socialismo num só país. É rigorosa e exclusivamente neste sentido que se pode afirmar que o pensamento lukacsiano ${ }^{41}$ escreve-se na mesma problemática global em que a era stalinista aparece como problemática setorial42; neste terreno comum a oposição de princípio que Lukács estabeleceu com a era stalinista concretizou o desenvolvimento possível do marxismo neste período adverso.

A problemática global aqui referida é a posta pelo fracasso da revolução no Ocidente. Não é possível nem pertinente discutir nesse lugar a complexa causalidade deste fenômeno e/ou as suas incidências dramáticas (nas quais a própria era stalinista avulta); mas indispensável enlaçá-la com o roteiro intelectual de Lukács. É o confinamento da revolução no "elo mais fraco da cadeia" (Lênin), a sua limitação ao Leste atrasado que vai determinar a evolução ulterior de Lukács; seu pensamento só é compreensível se conectado a essa problemática. Mesmo não sendo cabível refletir aqui sobre a revolução político-ideológica de Lukács, há que fazer notar que desde as vésperas da Crise de 1929 e , portanto, muito antes da viragem que se opera no VII Congresso do Komintern, Lukács já perdera as esperanças sobre a possibilidade de

\footnotetext{
${ }^{38}$. E isto é feito, com maior ou menor sucesso, pelos escolialistas lukacsianos. A tarefa é tanto mais ingênua quanto mais tem de destacar que os equívocos de Lukács, devidos à sua inserção histórico-política, não passam de momentos, episódios, acidentes etc... que não afetam o núcleo da sua obra. O autor dessas linhas conhece bem, por prática própria, os mecanismos dessa alquimia ideológica.

39. Desvio, aliás, é a proposta conceitual provisória de Althusser para caracterizar o stalinismo (cfr. 1973, p. 88).

40. Por isto, é verdadeiramente espantoso ouvir o murmúrio do último (?) Lefebvre em face da concepção político-estatal do stalinismo (e o logo Lefebvre!): "Le marxisme n'a qu'une responsabilité restreinte dans l'affaire" (cfr. 1976, p. 387).

41. Entenda-se: o pensamento de Lukács dos meados dos anos 20 em diante, pensamento que comporta inflexões. Não cabe aqui discutir a periodização da obra lukacsiana, a que já dediquei atenção noutro contexto e com outros objetivos.

${ }^{42}$. Numa perspectiva bem diversa da que utilizo aqui, Perry Anderson já relacionou a era stalinista e os problemas do “marxismo ocidental” (cfr. 1976).
} 
liquidar a curto prazo a dominação burguesa e extraíra daí amplas consequências táticas e estratégicas, tornando-se um coerente ideólogo da política de frente popular avant la lettre43; quando esta política é implementada no movimento operário revolucionário, a partir de 1935, ela encontra Lukács apetrechado para fundamentá-la teórica e ideologicamente - e nessa fundamentação localiza-se o travejamento básico da sua atividade nos anos 30 e 40.

O insulamento do socialismo num só país não significou para Lukács um azar histórico, uma contingência cujas aplicações afetariam apenas as táticas do movimento operário revolucionário num decurso temporal limitado (embora de duração variável). Para ele, significou um novo quadro histórico estrutural e inescamoteável, que não parecia destinado a problematizar, em medida expressiva o projeto revolucionário "clássico". Daí, consequentemente, que ele não tenha visto como tarefas teóricas prioritárias nem a análise dos intervenientes político-ideológicos que conduziram ao colapso as expectativas revolucionárias do imediato pós-guerra nem a investigação das novas condições de reprodução social do sistema capitalista, capazes de integrar (ainda que transitoriamente) na sua dinâmica os seus vetores negativos 44 . Ao contrário, como tarefa teórica ele se traçou o avanço do marxismo como se o isolamento do socialismo fora uma clivagem histórico-universal perfeitamente compatível com a herança dos "clássicos" do marxismo e como se a conjuntura da frente popular, de fato, não apenas garantisse contra "regressões" políticas, mas também constituísse uma estratégia bem mais ampla - no limite, abrindose talvez como alternativa de transição ao socialismo 45 .

Em poucas palavras: nos finais dos anos [19]20, Lukács fez uma claríssima opção por aquela via que ulteriormente receberia a pitoresca designação de "socialismo real". E foi esta opção que, em termos históricopolíticos, determinou necessariamente que as subsequentes intervenções

\footnotetext{
43. Como se infere das leituras das Teses de Blum (cfr. LUKÁCS, 1973, pp. 229 ss). A derrota destas posições e a insincera autocrítica que teve de realizar em seguida jamais abalaram a convicção pessoal de Lukács, conforme a qual a sua proposta política era correta (cfr., quanto a este ponto, o Prefácio de 1967, que ele escreveu para a reedição de História e consciência de classe [1965a]).

${ }^{44}$. Só no derradeiro Lukács, dos finais da década de [19]60, é que esta investigação apareceria; então, o conceito de manipulação social ocupará relevante lugar nas suas preocupações.

45. Daí que, nos anos em que emergia explicitamente a ideologia da "coexistência pacífica", ela jamais se tenha afigurado a Lukács como um instrumento conjuntural - antes, era a forma adequada e justa, histórica, teórica e ideologicamente para a condução da luta anticapitalista. A respeito, além das suas intervenções sobre este ponto em Conversando com Lukács, pode-se confrontar o seu ensaio Contribuição ao debate entre a China e a URSS, de 1963. Por outro lado, em várias posições de Lukács até meados dos anos 60, os eurocomunistas poderão joeirar argumentações favoráveis aos seus projetos.
} 
de Lukács, referidas à teoria e à prática 46 do movimento operário revolucionário, se efetivassem no interior do espaço estratégico-ideológico que a era stalinista, de fato a única conducente ao "socialismo real", instaurava 47.

Exatamente aquele situar-se na mesma problemática global que colocou a possibilidade objetiva da autocracia stalinista e tudo que ela incluiu e excluiu, bem como este movimentar-se no espaço estratégico ideológico instaurado pela dogmática é que aprisionam a oposição de princípio lukacsiana referida atrás ${ }^{48}$.

Estão dadas aí, sumariamente, as bases que enlaçam a dogmática da era stalinista com o pensamento lukacsiano - dois polos do mesmo complexo oriundo do fracasso da revolução no Ocidente. É nesta perspectiva - e só nesta - que me parece frutífero indagar o marxismo de Lukács como marxismo possível na era stalinista, como marxismo concreto que traz no seu bojo os signos inequívocos do seu tempo histórico 49.

É claro que uma tal opção histórico-política abria a Lukács um leque de possibilidades intelectuais e ideológicas: se lhe impunha um ângulo de apreciação que lhe restringia o universo de investigação, não lhe determinava, fatalmente, o modo de apropriar-se dele. A fraqueza de Lukács dimana daquele universo limitado; a sua duradoura força advém do tratamento que lhe dedicou.

Será trabalho de outro ensaio estudar detidamente a atenção dialética dessas forças centrífugas e centrípetas na obra lukacsiana, mas devo concluir essas aproximações indicando alguns aspectos do pensamento lukacsiano em que a incidência restritiva do seu posicionamento histórico-político me parece marcante.

Contra as adições e supressões arbitrárias que o oportunismo teórico da dogmática obrigatoriamente implicava, Lukács desenvolveu uma concepção do marxismo a que não é alheia a influência do Engels do Anti-Dühring (precisamente aquela a que Lênin devotará entusiasmo): um

\footnotetext{
${ }^{46}$. Embora ele se tivesse abstido de intervenções como político no intervalo entre a derrota das Teses de Blum e a preparação do levante húngaro de 1956.

47. Aliás explicitamente, Lukács jamais pôs em questão a justeza da opção de base que fundou aquele espaço; já vimos que, na Carta sobre o stalinismo, ele escreveu: "No que concerne aos problemas estratégicos então decisivos, Stálin teve plenamente razão contra Trotsky".

${ }^{48}$. Esclarece-se, assim, por exemplo, por que a Carta sobre o stalinismo continua a crítica do stalinismo no plano meramente superestrutural.

49. Signos que a maioria dos críticos tem localizado nos seus aspectos mais epidérmicos: ora as autocríticas de Lukács (as duas formais de 1929 e de 1949, consideradas insuficientes pelo establishment), ora o emprego de uma linguagem panfletária que destoa do conteúdo do seu pensamento (p. ex., algumas passagens de $A$ destruição $d a$ razão), ora a utilização de um exemplário francamente enganoso (como o uso que Lukács fez, em Existencialismo ou marxismo?, dos Processos de Moscou).
} 
sistema autossuficiente autônomo no que toca aos seus fundamentos. Essa paixão do sistema - na qual se poderia rastrear ainda a formação hegeliana do filósofo húngaro -, muitas vezes, deslocou-se das suas balizas metodológicas para o próprio conteúdo das investigações: não são raros os passos lukacsianos em que a premissa consiste, apesar da ressalva formal de que não se trata disto, na hipótese não verificada de que o marxismo já elucidou o nuclear, cabendo às pesquisas detalhar aspectos conjunturais. Numa palavra, a autonomia metodológica do marxismo passava a ser sua conclusão, o seu caráter cerrado, o seu resultado científico. A paixão do sistema, impaciente, substitui-se ao processo histórico efetivo. Daí a flagrante alergia aos novos dados postos pela evolução da cultura, que pode ser surpreendida em não poucos momentos da obra lukacsiana. É realmente chocante, por exemplo, constatar o alheamento de Lukács em face da pesquisa psicanalítica ${ }^{50}$ - e isto não é fortuito: frequentemente Lukács operou, frente à ciência contemporânea, especialmente aquela referida ao homem e à sociedade, com a estreita bitola da oposição vazia "ciência burguesa x ciência proletária".

O último Lukács pareceu ter consciência deste equívoco. Na parte publicada da sua derradeira grande obra, Ontologia do ser social (LUKÁCS, 1976), a paixão do sistema se desvanece repentinamente e o velho pensador não contou com tempo necessário para elaborar uma alternativa nova: descaiu numa perspectiva claramente empirista, de cuja abstração e riscos os perigos são evidentes para o analista experimentado $^{51}$. Aliás, o último Lukács é uma viva e desesperada autocrítica raramente explícita, do ideólogo que se nutriu com a mitologia do "socialismo real" ${ }^{52}$ : ele se pôs, seriamente, a questão de escrever um Capital adequado ao nosso tempo.

Ao colocar-se uma tarefa deste gênero, Lukács apenas patenteou a urgência de um conhecimento científico (dialético) do capitalismo tardio das suas novas características, das condições de reprodução social contemporânea etc. Precisamente o conhecimento de que a sua obra se recente medularmente - e não somente no que diz respeito ao capitalismo tardio como realidade estritamente econômica -: com efeito, entre 1936 e

\footnotetext{
${ }^{50}$. Não me refiro ao positivismo acrítico e à demagogia grosseira que se verificam geralmente na terapia psicanalítica e na sua vulgarização. O que é central é a ignorância de Lukács em face da problemática aberta por Freud.

${ }^{51}$. É óbvio, porém, que a paixão lukacsiana do sistema não é marginalizada pelas mesmas razões que levaram os pensadores de Frankfurt a evitá-la: para eles, mesmo o conceito de sistema interdita a liberdade (cfr. ADORNO, 1977).

52. Não é arbitrariamente que o arguto Michel Löwy conclui o seu ensaio Lukács and Stalinism com as seguintes palavras: "após meio século de "reconciliação" e de 'ilusões perdidas', Lukács retoma, nos seus três últimos anos de vida, com a redescoberta de intensas esperanças, a chama vermelha do comissário do povo de 1919” (1978, p. 82).
} 
1960, Lukács não avançou nada de significativo para a compreensão dos novos problemas sócio-históricos.

Por outro lado, é a esta lacuna que se deve debitar a miséria das passagens abertamente políticas da obra lukacsiana: quando aparecem ou são vincadas por um impressionismo conjuntural ou então são notações teóricas postas num tal nível de generalidade que suportam quaisquer elasticidades; até mesmo no Lukács posterior à denúncia pública da era stalinista a análise da política é de uma ingenuidade primária ${ }^{53}$. Somente quando tentou agarrar determinações da economia política do capitalismo tardio, tomado como fenômeno de dimensões novas, é que ele pôde esboçar algumas soluções inteligentes e dignas do seu talento; isso ocorre nos seus derradeiros esforços teóricos, quando ele procura avançar sobre o complexo da manipulação social. Contudo, ao fazê-lo, formula as questões de tal modo que reduzi-las ao real histórico é tarefa hercúlea: o seu nível de generalidade é tão intenso que os seus procedimentos teóricos e heurísticos fornecem a substancial impressão de uma abstratividade inflada - assim é que, na Ontologia do ser social, o esquema analítico põe em tela um processo de humanização em que a teleologia imanente à socialidade em movimento expressa-se no trabalho e nas grandes objetivações humanas, a ciência e arte; mas as mediações concretas entre estas instâncias parecem exiladas no país do nebuloso.

É evidente que essa problemática radica não tanto naquela paixão do sistema (justamente liquidada na Ontologia do ser social) quanto, especificamente, no estreitamento categorial das concepções que Lukács pôde articular no interior do processo de resistência histórica do sistema capitalista: a práxis desaparece do seu horizonte mental a partir do seu abandono do "esquerdismo" dos primeiros tempos como marxista. Decorrentemente, até a década de [19]60, a cotidianidade - esse sistema de interstícios por onde transita a historicidade concreta - é algo de inteiramente inapreensível para Lukács54. Até então, o seu marxismo decorre alienando do seu campo de investigação e de problemas as reais condições em que os homens do capitalismo tardio jogam as suas mais decisivas escolhas individuais e existenciais55 (no ocaso de Lukács, estas escolhas aparecem como problemas, e este processo de enfoque das dimensões básicas da vida social determinada historicamente não é estranho à simpatia do velho Lukács para com formas de espaço de intervenção sociopolítica que, na ótica dos defensores do "socialismo real",

\footnotetext{
53. Isto é particularmente óbvio quando ele trata da "era Kennedy", nas entrevistas de Conversando com Lukács; Mészáros, aliás, observou este aspecto (1972, pp. 88-9).

54. É somente na Estética I (1966a [1962]) que a preocupação (sistemática, aliás) com a cotidianidade vem à tona - e com o travo da abstração.

${ }^{55}$. Que não são questões existencialistas.
} 
são francamente "esquerdistas" - p. ex., a revalorização da democracia socialista assentada na atividade dos sovietes).

Mas a fraqueza e a força, os limites e a riqueza, a grandeza autenticamente "clássica" e a impermeabilidade em face dos novos problemas verdadeiros surgem com nitidez exasperante naquele que é o campo privilegiado da elaboração lukacsiana - o da estética. Aí o legado de Marx é genuinamente acrescido e a hipoteca do fracasso revolucionário na teoria mostra o alcance dos seus estragos.

Uma das consequências imperativas da defesa da estratégia da política do socialismo num só país e, logo, da frente popular era a valorização da herança cultural. Dificilmente será exagerada a significação do empreendimento teórico de Lukács56, o empreendimento de dar conteúdo a esse conceito e torná-lo eficazmente operatório; avançando sobre as indicações dos "clássicos", ele deixou um balanço conclusivo na análise 57 da literatura do período que vai dos primeiros balbuceios ideológicos burgueses à ascensão do nazi-fascismo. Esse empreendimento, Lukács levou-o a cabo combatendo, de um lado, o impressionismo crítico e, de outro, o positivismo sociológico que vinha de Plekhânov, assim como o vanguardismo oportunista de setores modernosos ${ }^{5}$, na salvaguarda do que, mais tarde, ele chamaria de die Eigenart de Äesthebistchen. Empreendimento que, no entanto, fez-se simultaneamente com uma franca ignorância da literatura contemporânea ou com a aplicação a ela de uma escala de valores indiscutivelmente inadequada59 - e pode-se questionar, com razão, a operacionalidade heurística de uma estética (geral) assim elaborada ${ }^{60}$.

O verdadeiramente emocionante, todavia, é a sinceridade do verdadeiro Lukács, o seu desesperado movimento para ser fiel ao objeto: realmente, é patético ver o gigantesco esforço do velho pensador, nos seus últimos momentos, correndo desajeitadamente contra o tempo e contra as suas próprias afirmações anteriores, tentando revisar os seus catastróficos equívocos judicativos e flexibilizar uma teoria estético-literária que contempla desfavoravelmente o que desborda os seus parâmetros rigidamente estabelecidos.

\footnotetext{
${ }^{56}$. Embora considerá-lo "Marx da estética" seja, sem dúvida, fazer injustiça a Marx - cuja empresa teórico-crítica foi capaz de compreender genialmente todas as manifestações significativas e pertinentes da sociedade capitalista do seu tempo. Com Lukács, não é propriamente isso que ocorre.

57. E análise dialética, superadora da falsa antinomia análise externa/análise imanente análise em que a explicação histórica funde-se organicamente à compreensão estética.

${ }^{58}$. Sobre essa questão, C. Prévost é elucidativo no texto já referido.

59. Os juízos de Lukács anteriores a meados da década de [19]60 sobre significativos autores do nosso tempo são um eloquente testemunho disto.

${ }^{60}$. Não é casual que precisamente a particularização de Lukács na Estética I seja inconveniente - cfr. as seções referentes à música, arquitetura, cinema etc.
} 
Entre a crítica lukacsiana elíptica dos anos 30 aos anos 50 e a denúncia aberta do último Lukács, posterior ao XX Congresso do PCUS, não há hiatos: há uma continuidade essencial, dissimulada somente pela linguagem fabular utilizada na era stalinista. Esta linguagem era o máximo a que se podia chegar quando se viveu o pior da autocracia stalinista sobre o seu próprio tacão; supô-la insuficiente e/ou frágil é ignorar crassamente as condições reais da vida soviética de então ou, o que não é menos discutível, é fazer a apologia do martírio cego que não vislumbra nenhuma transcendência além dos seus próprios limites.

Assim, tão somente uma investigação leviana ou preconceituosa pode questionar a oposição de princípio que Lukács sustentou, ao longo de três décadas ininterruptas ao dogmatismo e ao obscurantismo pretensamente socialistas, embora ela se tenha desenvolvido sobre a mesma problemática global em que se escreve a era stalinista.

Esta oposição, considerada em si mesma, não configura um mérito do pensador húngaro. Na verdade, não se deve fazer de uma necessidade uma virtude. Mas, entre os trânsfugas do marxismo e os fiéis servidores do burocratismo soi disant socialista, Lukács avulta com estatura modelar: a sua sobrevivência na noite da repressão é nutriz do princípio da esperança, que só se valida hoje enquanto estímulo para a superação dos seus próprios parâmetros.

Essa sobrevivência, Lukács não a conseguiu sem sacrifícios - de que sua obra é documento. Mas ela não lhe custou o ônus da convivência nem, muito menos, nódoas numa dignidade pessoal e intelectual que tem um cariz socrático.

Györg Lukács recusou-se ao martírio: entre sombras e luzes permaneceu guardião daquilo que acreditava serem as tradições metodológicas do marxismo.

\section{Referências bibliográficas}

ADORNO, T. Terminologia filosófica v. II. Madrid: Tauros, 1977.

ALTHUSSER, L. Resposta a John Lewis. Lisboa: Estampa, 1973.

ANDERSON, Perry. Coordinates of western Marxism. London: New Left, 1976.

BAHR, E. La pensée de Georg Lukács. Toulouse: Privat, 1972.

BARAN, Paul A. A economia política do desenvolvimento econômico. Rio de Janeiro: Zahar, 1960.

COUTINHO, Carlos Nelson. O estruturalismo e a miséria da razão. Rio de Janeiro: Paz e Terra, 1972.

DEUTSCHER, I. Stálin: a história de uma tirania. Rio de Janeiro: Civilização Brasileira, 1970. 2 v. 
EHRENBURG, I. Memórias. Rio de Janeiro: Civilização Brasileira, 1970. 3v.

ELLENSTEIN, J. Histoire du phénomène stalinien. Paris: Grasset, 1975.

. História da URSS. Lisboa: Pub. Europa-América, 1976.

GORKI, M.; ZDHANOV, A. A. Literatura, filosofia, marxismo. México: Grijalbo, 1968.

HOLZ, H.; KOFLER, Leo; ABENDROTH, W. Conversando com Lukács. Rio de Janeiro: Paz e Terra, 1969.

KONDER, Leandro. Os marxistas e a arte. Rio de Janeiro: Civilização Brasileira, 1967.

LEFEBVRE, H. De l'État: 2. De Hegel a Mao par Staline. Paris: UGE, 1976. LÖWY, Michel. Lukács and Stalinism. In: VVAA. Western Marxism: a critical reader. London: Verso, 1978.

LUKÁCS, G. El joven Hegel y los problemas de la sociedad capitalista. México: Grijalbo, 1963.

. Histoire et concience de classe. Paris: Minuit, 1965a.

. Le roman historique. Paris: Payot, 1965b.

. Estética v. I. Barcelona-México: Grijalbo, 1966a.

- Aportaciones a la historia de la estética. México: Grijalbo, 1966b.

1966c.

. Problemas del realismo. México: Fundo de Cultura Económica, . El asalto a la razón. Barcelona/México: Grijalbo, 1968a.

- Marxismo e teoria da literatura. Rio de Janeiro: Civilização Brasileira, 1968b.

. Sociología de la literatura. Barcelona, Ed. P. Ludz/Peninsula, 1968c.

. Realismo crítico hoje. Brasília: Coordenada, 1969.

. "Lenin y los problemas del período de transición". In Lenin: la coerencia de su pensamiento. México, Grijalbo, $1970 a$.

. Soljenitsyne. Paris: Gallimard, 1970b.

. Realistas alemanes del siglo XIX. Barcelona/México: Grijalbo, 1970c.

68, July 1971.

. Entrevista a P. Anderson [1969]. New Left Review, London, n.

. Tactics and ethics: political writings, 1919/1929. London: New Left, 1973.

. Écrits de Moscu. Paris: Éd. Sociales, 1974.

. Ontologia dell'essere sociale v. I. Roma: Riuniti, 1976.

- Carta sobre o stalinismo. Temas de Ciências Humanas, São

Paulo, n. 1, 1977. 
. Littérature, philosophie, marxisme (1922/1923). Paris: PUF,

1978.

. Existencialismo ou marxismo? Ciências Humanas: São Paulo, 1979.

MANDEL, E. Crítica do eurocomunismo. Lisboa: Antídoto, 1978.

MÉSZÁROS, I. Lukács' Concepto of dialectic. London: Merlin, 1972.

MOUNIN, G. Historia de la linguística. Madrid: Gredos, 1968.

TROTSKY, L. A revolução permanente [1928]. São Paulo: Ciências Humanas, 1978.

PAPAIOANNOU, K. Marx et les marxistes. Paris: Flammarion, 1972.

POSADA, Francisco. Lukács, Brecht e a situação atual do realismo socialista. Rio de Janeiro: Civilização Brasileira, 1970.

REVAI, J. Excerto de artigo escrito em 1952. Les Temps Modernes, Paris, n. 129/130/131, nov.-déc. 1956/jan. 1957.

SARTRE, J.-P. Existencialismo ou marxismo? São Paulo: Ciências Humanas, 1979.

SEMPRUN, Jorge. Autobiografia de Federico Sánchez. Madrid: Planeta, 1977.

SĖVE, Lucien. Reflexões sobre o dogmatismo. Revista Civilização Brasileira, Rio de Janeiro, ano I, n. 3, jul. 1965.

STALIN, J. V. Marxism and problems of linguistics. Pequin: Foreign Languages, 1972.

Como citar:

NETTO, José Paulo. Lukács e a problemática cultural da era stalinista. Verinotio - Revista on-line de Filosofia e Ciências Humanas, Rio das Ostras, v. 25, n. 1, pp. 303-38, abr. 2019.

Data de envio: 10 dez. 2018

Data de aceite: 27 jan. 2019 